\title{
The influence of proton pump inhibitors on the effect of clopidogrel on the risk of recurrent ischemic stroke
}

\author{
Endang Mahati ${ }^{1 *}$, Jarir Atthobari ${ }^{2}$, Ngatidjan ${ }^{2}$ \\ ${ }^{1}$ Department of Pharmacology, Faculty of Medicine, Universitas Diponegoro, Semarang, \\ ${ }^{2}$ Department of Pharmacology, Faculty of Medicine, Universitas Gadjah Mada, \\ Yogyakarta, Indonesia
}

DOI: http://dx.doi.org/10.19106/JMedSci004702201503

\begin{abstract}
Patients surviving with a stroke have an increased risk for recurrent stroke. Clopidogrel is widely used to prevent recurrent stroke. However, clopidogrel may cause gastrointestinal bleeding (GIB). Therefore, proton pump inhibitors (PPIs) are recommended to reduce the side effect of clopidogrel. Unfortunately, these both drugs are metabolized in the liver by the same enzyme i.e. cytochrome P4502C19 (CYP219) that may reduce the effect of clopidogrel. The aim of this study was to evaluate the influence of PPIs on the effect of clopidogrel in the prevention of recurrent stroke. It was a hospital-based case control study conducted in Bethesda Private Hospital, Yogyakarta involving 392 patients with recurrent stroke as cases and 784 patients with first-ever stroke as controls. The exposure of PPIs during clopidogrel therapy on both cases and controls groups were recorded from prescription records for at least six months before index date. The duration of PPIs exposure were categorized as current expoure (less than two months before the index date) and recent exposure (2-6 months before the index date). The result showed there was no influence of PPls exposure on the effect of clopidogrel on the risk of recurrent ischemic stroke (OR: $1.00 ; 95 \% \mathrm{Cl}$ : 0.56-1.79). Moreover, the current use of PPIs and clopidogrel could decrease the risk of recurrent ischemic stroke (OR: 0.04; $95 \%$ $\mathrm{Cl}$ : 0.01-0.41). In conclusion, there is no association between PPI exposure and the risk of recurrent stroke in patients receiving clopidogrel.
\end{abstract}

\section{ABSTRAK}

Penderita strok mempunyai risiko stroke berulang lebih tinggi. Klopidogrel digunakan secara luas untuk mencegah stroke berulang. Namun demikian klopidogrel kemungkinan menyebabkan pendarahan gastrointestinal. Oleh karena itu penghambat pompa proton (PPP) dianjurkan diberikan untuk mengurangi risiko efek samping klopidogrel. Sayangnya kedua obat ini dimetabolisme di hepar oleh enzim yang sama (CYP2C19) yang kemungkinan dapat menurunkan efek klopidogrel. Tujuan penelitian ini adalah mengkaji pengaruh pemberian PPP terhadap efek klopidogrel dalam mencegah stroke berulang. Penelitian ini merupakan penelitian kasus control berbasis rumah sakit yang dilakukan di Rumah Sakit Bethesda, Yogyakarta. Sebanyak 392 pasien yang mengalami stroke berulang sebagai kasus dan 784 pasien yang pertama kali menderita stroke sebagai control. Pemberian 


\begin{abstract}
PPP selama pengobatan dengan klopidogrel pada kedua kelompok diambil dari catatan peresepan sejak enam bulan terakhir mulai dari tanggal kedatangan. Pemberian PPP dikelompokan dalam dua kelompok yaitu pemberian $<2$ bulan dan antara 2-6 bulan sejak tanggal kedatangan. Hasil penelitian menunjukkan tidak ada pengaruh pemberian PPP terhadap efek klopidogrel pada risiko terjadinya stroke berulang (OR: 1,00; 95\% Cl: $0,56-1,79)$. Selain itu, pemberian PPP dan klopidogrel $<2$ bulan sejak kedatangan dapat menurunkan risiko stroke berulang (OR: 0,04; $95 \% \mathrm{Cl}$ : 0,01-0,41). Dapat disimpulkan tidak ada hubungan antara pemberian PPP dan risiko stroke berulang pada pasien yang menerima klopidogrel.
\end{abstract}

Keywords: clopidogrel - proton pump inhibitors - recurrent stroke - interaction

\section{INTRODUCTION}

Stroke is a common form of cardiovascular disease affecting the blood supply to the brain. Stroke is one of the leading causes of morbidity and mortality worldwide. ${ }^{1}$ Of the approximately 16.9 million strokes that occur annually, over $80 \%$ are ischemic stroke. Nearly six million die and another five million are left permanently disabled annually. ${ }^{2-4}$ In Indonesia, Stroke is the first leading cause of death and its prevalence is 7.0 per 1000 population. ${ }^{5}$ Data launched by Bethesda Private Hospital, Yogyakarta showed that 800-1000 cases of stroke has been reported annually.

Patients surviving with a stroke or transient ischemic attack (TIA) have an increased risk for recurrent stroke. Without secondary prevention, the risk for recurrent stroke is 30$40 \%$ among patients with stroke during $5^{\text {st }}$ year after the primary event. Whereas among patients with TIA, the risk for recurrent stroke is $8-12 \%$ after seven days post TIA and more than $20 \%$ among the another groups of patients with stroke. ${ }^{6}$ Therefore, secondary prevention has been strongly recommended to reduce the risk for recurrent stroke. ${ }^{7,8}$

Clopidogrel is a thienopyridine-class antiplatelet agent that acts by inhibits platelet activation induced by adenosine diphosphate
(ADP). ${ }^{7}$ Clopidogrel is widely used to prevent recurrent stroke. Clopidogrel alone or in combination with aspirin has successfully proved its benefit in the prevention the recurrent stroke. ${ }^{7,9,10}$ However, the use of clopidogrel is often associated with an increased risk of upper gastrointestinal bleeding (UGIB). ${ }^{10,11}$ To reduce the risk of UGIB, clopidogrel is recommended in combination with proton pump inhbitors (PPIs) to prevent the recurrent stroke. ${ }^{7,12}$

Clopidogrel is a prodrug that must be metabolized in the liver mainly by cytochrome P-4502C19 isoenzymes (CYP2C19) to generate an active metabolite. Moreover, CYP2C19 is also involved in the metabolisms of PPIs. Therefore, the interaction between clopidogrel and PPIs may be occurred in the concomitant use of these drugs. However, previous studies showed that the interaction between clopidogrel and PPIs have not been clearly proven. It was reported that omeprazole would reduce the antiplatelet effect of clopidogrel lead to increase the risk of stroke, death, myocardial infarction and unstable angina. ${ }^{13-17}$ In contrast, other studies showed no association between coadministration of PPIs in patients receiving clopidogrel with the risk of cardiovascular adverse events including recurrent stroke. ${ }^{18-20}$ This study was conducted to prove the effect 
of PPIs on recurrent stroke in patients treated with clopidogrel following ischemic stroke.

\section{MATERIALS AND METHODS}

\section{Subjects}

The study was a hospital-based case control study conducted in Bethesda Private Hospital, Yogyakarta involving patients surviving with an ischemic stroke aged 18-65 years who were discharged from the hospital between December 2011 and June 2012. The study was approved by the Medical and Health Research Ethics Committee of Universitas Gadjah Mada, Yogyakarta.

\section{Procedures}

Data of stroke patients were collected from medical record of patients including stroke registry and inpatient book registry at Bethesda Private Hospital, Yogyakarta. Based on medical record from Medical Record Installation at the hospital, the ischemic stroke patients were then classified into patients with recurrent stroke and patients with first-ever stroke. The patients with recurrent stroke were defined as cases with the inclusion criteria were as follows: 1) all patients with recurrent stroke during $5^{\text {st }}$ year after the primary event; 2) aged more than 18 years. The exclusion criteria of the cases were as follows: 1) having a not complete medical record; 2) having an history of liver and renal diseases in the last six months until the onset of recurrent ischemic stroke observed; 3) suffering a gastroesophageal reflux disease and peptic ulcers. The patients with firstever stroke were defined as control with the inclusion criteria were as follows: 1) patients with first-ever stroke and were controlling in outpatient polyclinic; 2) aged more than 18 years. The exclusion criteria of the control were as follows: 1) having a not complete medical record; 2) having an history of liver and renal diseases in the last six months until visiting at outpatient polyclinic; 3) suffering a gastroesophageal reflux disease and peptic ulcers. The study was designed to have 2:1 matching, with two controls for each cases. The matching criteria were gender, age (born within 5 years) and index date (within 2 weeks). The exposure of PPIs during clopidogrel therapy on both cases and controls groups were recorded from prescription records for at least 6 months before index date. The types of PPIs administered including omeprazole, esomeprazole, lansoprazole and pantoprazole were recorded. The duration of PPIs exposure was categorized as current exposure (less than 2 months before the index date) and recent exposure (2-6 months before the index date).

\section{Statistical analysis}

Conditional logistic regression analysis was used to estimate the odds ratio (OR) for the association between recurrent stroke and exposure to a PPI, using as the reference group of patients with no prescription for a PPI. The factors which may interfere with the outcome including history of diabetes, blood pressure, lipid profile, Charlson comorbidity index, and the drugs use as a co-medication for the patients, such as statin, antiplatelet (low dose ASA), diuretics, ACE inhibitors, angiotensin receptor blockers, CYP inducers, CYP inhibitors, calcium channel blockers and $\beta$-blockers were adjusted. The data obtained were analyzed using Chi square test for bivariate and logistic regression for multivariate using a statistic software.

\section{RESULTS}

Over the 18-months study period, 1,479 patients surviving with an ischemic stroke aged 45 years or older were identified. The 
patients were selected using consecutive method in order to classify into cases and controls groups. A total 392 patients with recurrent stroke as cases and 784 patients with first-ever stroke as controls were identified and recruited in this study. The characteristics of cases and controls are presented in TABLE 1. The characteristics of cases were likely similar in term of gender and sex. However, the cases were more likely to have a history of hypertension and dibetes mellitus. The significant difference in mediations use between cases and controls especially for ACE inhibitors, ARB, $\beta$-blockers, $\mathrm{Ca}$ channel blockers, statin, CYP inducers, CYP ihibitors and low dose ASA were observed in this study $(p<0.05)$. Moreover, the Charlson index between cases and controls was also significantly different $(\mathrm{p}<0.05)$.

TABLE 1. Characteristics of subjects of cases and controls

\begin{tabular}{|c|c|c|c|}
\hline Variables & $\begin{array}{c}\text { Cases } \\
(\mathrm{n}=392)\end{array}$ & $\begin{array}{l}\text { Controls } \\
(n=784)\end{array}$ & $\mathrm{p}$ \\
\hline \multicolumn{4}{|l|}{ Sex } \\
\hline - Male & $229(58.4 \%)$ & $458(58.4 \%)$ & \multirow{2}{*}{1.000} \\
\hline - Female & $163(41.6 \%)$ & $326(41.6 \%)$ & \\
\hline \multicolumn{4}{|l|}{ Age (year) } \\
\hline - 75 уо & $62(15.8 \%)$ & $119(15.2 \%)$ & \multirow{4}{*}{0.163} \\
\hline - $60-74$ yo & $185(47.2 \%)$ & $327(41.2 \%)$ & \\
\hline - 45-59 уо & $131(33.4 \%)$ & $295(37.6 \%)$ & \\
\hline - $<45$ & $14(3.6 \%)$ & $43(5.5 \%)$ & \\
\hline \multicolumn{4}{|l|}{ Blood pressure } \\
\hline - Hypertension & $159(40.6 \%)$ & $159(20.3 \%)$ & \multirow{2}{*}{$<0.001$} \\
\hline - Normal & $233(59.4 \%)$ & $625(79.7 \%)$ & \\
\hline \multicolumn{4}{|l|}{ Glycemic index } \\
\hline - Uncontrolled DM & $104(26.5 \%)$ & $165(21.0 \%)$ & \multirow{4}{*}{0.001} \\
\hline - Controlled DM & $26(6.6 \%)$ & $35(4.5 \%)$ & \\
\hline - Normoglycemia & $241(61.5 \%)$ & $565(72.1 \%)$ & \\
\hline - No info & $21(5.4 \%)$ & $19(2.4 \%)$ & \\
\hline \multicolumn{4}{|l|}{ Lipid profile } \\
\hline - Dyslipidemia & $221(56.4 \%)$ & $492(62.8 \%)$ & \multirow{3}{*}{0.080} \\
\hline - Non dyslipidemia & $140(35.7 \%)$ & $247(31.5 \%)$ & \\
\hline - No info & $31(7.9 \%)$ & $45(5.7 \%)$ & \\
\hline \multicolumn{4}{|l|}{ ACE inhibitor } \\
\hline - No & $335(85.5 \%)$ & $717(91.5 \%)$ & \multirow{2}{*}{0.002} \\
\hline - Yes & $57(14.5 \%)$ & $67(8.5 \%)$ & \\
\hline \multicolumn{4}{|l|}{ ARB } \\
\hline - No & $331(84.4 \%)$ & $608(77.6 \%)$ & \multirow{2}{*}{0.006} \\
\hline - Yes & $61(15.6 \%)$ & & \\
\hline \multicolumn{4}{|l|}{$\beta$-blocker } \\
\hline - No & $379(96.7 \%)$ & $774(98.7 \%)$ & \multirow{2}{*}{0.017} \\
\hline - Yes & $13(3.3 \%)$ & $10(1.3 \%)$ & \\
\hline
\end{tabular}




\begin{tabular}{|c|c|c|c|}
\hline \multicolumn{4}{|c|}{ Ca channel blocker } \\
\hline - $\mathrm{No}$ & $292(74.5 \%)$ & $538(68.6 \%)$ & \multirow{2}{*}{0.037} \\
\hline - Yes & $100(25.5 \%)$ & $246(31.4 \%)$ & \\
\hline \multicolumn{4}{|l|}{ Diuretic } \\
\hline - No & $366(93.4 \%)$ & $712(90.8 \%)$ & \multirow{2}{*}{0.136} \\
\hline - Yes & $26(6.6 \%)$ & $72(9.2 \%)$ & \\
\hline \multicolumn{4}{|l|}{ Statin } \\
\hline - No & $317(80.9 \%)$ & $466(59.4 \%)$ & \multirow{2}{*}{$<0.001$} \\
\hline - Yes & $75(19.1 \%)$ & $318(40.6 \%)$ & \\
\hline \multicolumn{4}{|l|}{ OAD } \\
\hline - No & $308(78.6 \%)$ & $614(78.3 \%)$ & \multirow{2}{*}{0.920} \\
\hline - Yes & $84(21.4 \%)$ & $170(21.7 \%)$ & \\
\hline \multicolumn{4}{|c|}{ CYP inducer } \\
\hline - Yes & $43(11.0 \%)$ & $116(14.8 \%)$ & \multirow{2}{*}{0.070} \\
\hline - No & $349(89.0 \%)$ & $668(85.2 \%)$ & \\
\hline \multicolumn{4}{|c|}{ CYP inhibitor } \\
\hline - Yes & $81(20.7 \%)$ & $328(41.8 \%)$ & \multirow{2}{*}{$<0.001$} \\
\hline - No & $311(79.3 \%)$ & $456(58.2 \%)$ & \\
\hline \multicolumn{4}{|c|}{ Low dose ASA } \\
\hline - No & $218(55.6 \%)$ & $146(18.6 \%)$ & \multirow{2}{*}{$<0.001$} \\
\hline - Yes & $174(44.4 \%)$ & $638(81.4 \%)$ & \\
\hline \multicolumn{4}{|c|}{ Charlson index } \\
\hline - $\geq 2$ & $165(42.1 \%)$ & $262(33.4 \%)$ & \multirow{2}{*}{0.004} \\
\hline - $<2$ & $227(57.9 \%)$ & $522(66.6 \%)$ & \\
\hline
\end{tabular}

ACE inhibitor: angiotensin converting enzyme inhibitor; $\mathrm{ARB}$ : angiotensin receptor blocker; OAD: oral antidiabetic; CYP inducer: cytochrome P-450 2C19 inducers; CYP inhibitor: cytochrome P-450 2C19 inhibitors; ASA: acetylsalicylic acid

No influence of PPIs exposure on the effect of clopidogrel on the risk of recurrent ischemic stroke was observed in this study (OR: 1.00; 95\% CI: 0.56-1.79) (TABLE 2). Furthermore, sub group analysis to the patients receiving clopidogrel also showed no influence of PPIs exposure on the risk of recurrent stroke (OR: 1.35; 95\% CI: 0.61-2.96) (TABLE 3).

TABLE 2. Risk factor of PPIs and clopidogrel exposures on the risk of recurrent ischemic stroke

\begin{tabular}{|c|c|c|c|c|}
\hline \multirow{3}{*}{ Exposure } & \multicolumn{2}{|c|}{ Recurrent stroke } & \multirow{3}{*}{$\mathrm{p}$} & \multirow{3}{*}{ OR $(95 \% \mathrm{CI})$} \\
\hline & Cases & Controls & & \\
\hline & $(n=392)$ & $(n=784)$ & & \\
\hline With PPI & $18(4.6 \%)$ & $36(4.6 \%)$ & \multirow{3}{*}{1.000} & $1.00(0.56-1.79)$ \\
\hline Without PPI & $374(95.4 \%)$ & $748(95.4 \%)$ & & Reference \\
\hline Total & $392(100.0 \%)$ & $784(100.0 \%)$ & & \\
\hline
\end{tabular}


TABLE 3. Influence of PPIs exposure to the patients receiving clopidogrel therapy on the risk of recurrent ischemic stroke

\begin{tabular}{|c|c|c|c|c|c|c|c|}
\hline \multirow{3}{*}{ Exposure } & \multicolumn{4}{|c|}{ Stroke } & \multirow{3}{*}{$\mathrm{p}$} & \multirow{3}{*}{$\begin{array}{l}\text { Unadjusted OR } \\
\qquad(95 \% \mathrm{CI})\end{array}$} & \multirow{3}{*}{$\begin{array}{l}\text { Adjusted OR* } \\
\qquad(95 \% \mathrm{CI})\end{array}$} \\
\hline & \multicolumn{2}{|c|}{ Recurrent } & \multicolumn{2}{|c|}{ Not recurrent } & & & \\
\hline & $\mathrm{n}$ & $\%$ & $n$ & $\%$ & & & \\
\hline With PPI & 18 & 24.3 & 36 & 12.6 & \multirow{3}{*}{0.12} & $2.22(1.18-4.19)$ & \multirow[t]{3}{*}{$1.35(0.61-2.96)$} \\
\hline Without PPI & 56 & 75.7 & 249 & 87.4 & & Reference & \\
\hline Total & 74 & 100.0 & 285 & 100.0 & & & \\
\hline
\end{tabular}

* Adjusted for age, gender, blood pressure, history of diabetes, use of ACE inhibitors, ARB, $\beta$-blockers, $\mathrm{Ca}$ channel blockers, diuretics, statin, OAD, CYP induers, CYP inibitors, low dose ASA and Charlson index.

Whereas subgroup analysis to the duration PPIs exposure showed that the current exposure of PPIs could reduce the risk of recurrent stroke OR 0.04 (95\% CI 0.01 to $0.41)$.

TABLE 4. Risk factor of duration of PPIs exposure on the risk of recurrent ischemic stroke

\begin{tabular}{|c|c|c|c|c|c|c|}
\hline \multirow{3}{*}{ PPI Exposure } & \multicolumn{4}{|c|}{ Stroke } & \multirow{3}{*}{\multicolumn{2}{|c|}{$\begin{array}{l}\text { Unadjusted OR } \\
\qquad(95 \% \mathrm{CI})\end{array}$}} \\
\hline & \multicolumn{2}{|c|}{ Recurrent } & \multicolumn{2}{|c|}{ Not recurrent } & & \\
\hline & $\mathrm{n}$ & $\%$ & $\mathrm{n}$ & $\%$ & & \\
\hline Current PPI & 11 & 61.1 & 35 & 97.2 & 0.001 & $0.04(0.01-0.41)$ \\
\hline Recent PPI & 7 & 38.9 & 1 & 2.8 & & Reference \\
\hline Total & 18 & 100.0 & 36 & 100.0 & & \\
\hline
\end{tabular}

In this study, omeprazole was the most common type of PPIs used in combination with clopidogrel on patients surviving stroke at Bethesda Private Hospital. Moreover, omeprazole (OR: 0.04; 95\% CI: $0.01-0.41$ ) could reduce the risk of recurrent stroke more better than esomeprazole (TABLE 5).

TABLE 5. The effect of PPI types on the risk of recurrent stroke

\begin{tabular}{|c|c|c|c|c|c|c|}
\hline \multirow{3}{*}{ PPIs } & \multicolumn{4}{|c|}{ Stroke } & \multirow{3}{*}{$\mathrm{p}$} & \multirow{3}{*}{ OR $(95 \% \mathrm{CI})$} \\
\hline & \multicolumn{2}{|c|}{ Cases } & \multicolumn{2}{|c|}{ Controls } & & \\
\hline & $\mathrm{n}$ & $\%$ & $\mathrm{n}$ & $\%$ & & \\
\hline Omeprazole & 10 & 55.6 & 22 & 61.0 & 0.461 & $0.46(0.56-3.70)$ \\
\hline Lansoprazole & 6 & 33.3 & 11 & 30.6 & 0.589 & $0.54(0.06-4.91)$ \\
\hline Pantoprazole & 0 & 0 & 1 & 2.8 & 0.361 & - \\
\hline Esomeprazole & 2 & 11.1 & 2 & 5.6 & Ref & \\
\hline Total & 18 & 100.0 & 36 & 100.0 & & \\
\hline
\end{tabular}




\section{DISCUSSION}

In this hospital-based study, PPI exposure to the ischemic stroke patients did not influence the effect of clopidogrel on the risk of recurrent ischemic stroke event. The influence of PPI on the effect of clopidogrel on stroke patients has been reported by some authors with different results. Some authors reported that PPIs exposure might influence the effect of clopidogrel, whereas other authors might not influence.

O'Donoghue et al ${ }^{17}$ reported that there is no association between the PPI use and risk of cardiovascular adverse events in patients receiving clopidogrel (adjusted hazard ratio/ HR: 0.94; 95\% CI: 0.80-1.11). In addition, Bhatt et al..$^{18}$ also reported that there is no association between the omeprazole use and the risk of cardiovascular events in patients receiving clopidogrel (HR: $1.02 ; 95 \% \mathrm{CI}$ : 0.70-1.51). No association between PPIs use and a significantly increased risk of recurrent stroke (adjusted odds ratio/AOR: 1.05; 95\% CI: 0.60 - 1.82) or death (AOR: 1.84; 95\% CI: 0.88-3.89) was also reported among older patients treated with clopidogrel after stroke. ${ }^{19}$

Different results concerning the influence of PPI on the effect of clopidogrel have been also reported by some authors. Gilard et $a l .{ }^{12}$ reported that omeprazole significantly decreased the effect of clopidogrel on platelet. Furthermore, Juurlink et $a l .{ }^{13}$ reported that current use of PPIs was associated with an increased risk of reinfarction (adjusted OR: 1.27 ; 95\% CI: 1.03-1.57). It was also reported that concomitant use of clopidogrel and PPI after hospital discharge for acute coronary syndrome was associated with an increased risk of adverse outcomes. ${ }^{14,15}$ In addition, concomitant use of a PPI and clopidogrel compared with clopidogrel alone was associated with a higher rate of major adverse cardiovascular events within 1 year after coronary stent placement. ${ }^{16}$
Both clopidogrel and PPIs are metabolized in the liver by CYP2C19. Therefore, the potential interaction between clopidogrel and PPIs may be occurred in the concomitant administration of the both drugs. Previous in vitro studies showed that PPIs could attenuate the antiplatelet of clopidogrel. ${ }^{21,22}$ However, this study showed that the potential interaction between clopidogrel and PPIs did not give clinical implications in patients with ischemic stroke.

Some limitations of this study were suspected. Data of duration of the drug use were not available; therefore, misclassification bias of long exposure of the drug could be occurred. Furthermore, data of doses of drug use could not be obtained. The doses of drug use might influence the clinical implication of the drug interaction that happened.

\section{CONCLUSION}

Among patients receiving with clopidogrel after ischemic stroke, PPIs exposure does not influence the effect of clopidogrel on the risk of recurrent ischemic stroke event. Therefore, it can be concluded that there is no association between PPIs exposure and the risk of recurrent stroke in patients receiving clopidogrel.

\section{ACKNOWLEDGMENTS}

The authors would like to thank all the Directors of Bethesda Private Hospital, Yogyakarta for their permission to perform this study. The study became possible with the assistance of all employees of the hospital.

\section{REFERENCES}

1. Lopez AD, Mathers CD, Ezzati M, Jamison DT, Murray CJ. Global and regional burden of disease and risk factors, 2001: systematic analysis of population health data. 
Lancet 2006; 367: 1747-57. http://dx.doi. org/10.1016/S0140-6736(06)68770-9

2. Thrift AG, Cadilhac DA, Thayabaranathan T, Howard G, Howard VJ, Rothwell MP et al., Gobal stroke statistics. Int J Stroke 2014; 9:618. http://dx.doi.org/10.1111/ijs.12245

3. Thrift AG, Cadilhac DA, Thayabaranathan T, Howard G, Howard VJ, Rothwell PM, Donnan GA. Global stroke statistics. Int J Stroke 2014; 9(1):6-18 DOI: 10.1111/ ijs. 12245 .

4. World Health Organization. Health situation in the South-East Asia Region 2001-2007. New Delhi: WHO Regional Publication, South-East Asia Series, No. 46, 2008.

5. Ministry of Health of Republic Indonesia. Indonesia Basic Health Research 2013. Jakarta: National Institute of Health Research and Development; 2013.

6. Roger VL, Go AS, Jones DM, Adams RJ, Berry JD, Brown TM, et al. Heart disease and stroke statistics 2011 update: a report from the American Hearth Association. Circulation 2011; e18-209. http://dx.doi.org/10.1161/ CIR.0b013e3182009701

7. American Heart Association (AHA). Guidelines for prevention of stroke in patients with ischemic stroke or transient ischemic attack. Stroke 2006; 37:577-617. http://dx.doi. org/10.1161/01.STR.0000199147.30016.74

8. La Loux P, Lemonnier F and Jamart J. Risk factors and treatment of stroke at the time of recurrence. Acta Neurol Belg, 2010; 110: 299-302.

9. Sacco RL, Diener HC, Yusuf S, Cotton D, Ounpuu S, Lawton WA, et al. Aspirin and extended-release dipyridamole vs clopidogrel for recurrent stroke. N Engl J Med 2008; 359(12):1238-51. http://dx.doi.org/10.1056/ NEJMoa0805002

10. Diener HC, Bogousslavsky J, Brass LM, Cimminiello C, Csiba L, Kaste M, et al. Aspirin and clopidogrel compared with clopidogrel alone after recent ischemic stroke or transient ischemic attack in high-risk patients (MATCH): randomized, doubleblind, placebo-controlled trial. Lancet 2004; 364(9431):331-7.

http://dx.doi.org/10.1016/S01406736(04)16721-4

11. Yusuf S, Zhao F, Mehta SR, Chrolavicius S, Tognoni G, Fox KK. Effects of clopidogrel in addition to aspirin in patients with acute coronary syndromes without ST-segment elevation. N Engl J Med 2001;345:494-502. http://dx.doi.org/10.1056/NEJMoa010746

12. Gilard M, Arnaud B, Le Gal G, Abgrall JF, Boschat J. Influence of omeprazole on the antiplatelet action of clopidogrel associated to aspirin. J Thromb Hemost 2006; 4(11):2508-9. http://dx.doi.org/10.1111/j.1538-7836.2006. 02162.x

13. Juurlink DN, Gomes T, Ko DT, Szmitko PE, Austin PC, Tu JV, et al. A population-based study of the drug interaction between proton pump inhibitors and clopidogrel. CMAJ 2009; 180(7):713-8.http://dx.doi.org/10.1503/ cmaj.082001

14. Ho PM, Maddox TM, Wang L, Fihn SD, Jesse RL, Peterson ED, et al. Risk of adverse outcomes associated with concomitant use of clopidogrel and proton pump inhibitors following acute coronary syndrome. JAMA 2009; 301(9):937-44. http://dx.doi. org/10.1001/jama.2009.261

15. Stanek EJ, Aubert RE, Flockhart DA. A national study of the effect of individual proton pump inhibitors on cardiovascular outcomes in patients treated with clopidogrel following coronary stenting: the clopidogrel medco outcomes study. Proceeding of the SCAI $32^{\text {nd }}$ Annual Scientific Sessions. Las Vegas, NV, 2009.

16. Kreutz RP, Stanek EJ, Aubert R, Yao J, Breall JA, Desta Z, et al. Impact of proton pump inhibitors on the effectiveness of 
clopidogrel after coronary stent placement: the clopidogrel medco outcomes study. Pharmacotherapy 2010; 30(8):787-96. http:// dx.doi.org/10.1592/phco.30.8.787

17. O'Donoghue ML, Braunwald E, Antman EM, Murphy SA, Bates ER, Rozenman Y, et al. Pharmacodynamic effect and clinical efficacy of clopidogrel and prasugrel with or without a proton pump inhibitor: an analysis of two randomised trials. Lancet 2009; 374(9694):989-97. http://dx.doi.org/10.1016/ S0140-6736(09)61525-7

18. Bhatt DL, Cryer BL, Contant CF, Cohen M, Lanas A, Schnitzer TJ, et al. Clopidogrel with or without omeprazole in coronary artery disease. NEngl J Med 2010;363(20):1909- 17. http://dx.doi.org/10.1056/NEJMoa1007964

19. Juurlink DN, Gomes T, Mamdani MM, Gladstone DJ, Kapral MK. The safety of proton pump inhibitors and clopidogrel in patients after stroke. Stroke 2011; 42(1):128- 32. http://dx.doi.org/10.1161/ STROKEAHA. 110.596643
20. Brown TM, Voeks JH, Bittner V, Safford MM. Variations in prevalent cardiovascular disease and future risk by metabolic syndrome classification in the reasons for geographic and racial differences in stroke (REGARDS) study. Am Heart J 2010; 159(3):385-91. http://dx.doi.org/10.1016/j.ahj.2009.12.022

21. Gilard M, Arnaud B, Cornily JC, Le Gal G, Lacut K, Le Calvez G, et al. Influence of omeprazole on the antiplatelet action of clopidogrel associated with aspirin: the randomized, double-blind OCLA (Omeprazole CLopidogrel Aspirin) study. J Am Coll Cardiol. 2008;51:256-60. http:// dx.doi.org/10.1016/j.jacc.2007.06.064

22. Sibbing D, Morath T, Stegherr J, Braun S, Vogt W, Hadamitzky $\mathrm{M}$, et al. Impact of proton pump inhibitors on the antiplatelet effects of clopidogrel. Thromb Haemost 2009; 101:714-9. 